Original Article

\title{
Factors Related The Job Satisfaction Among Migrant Nurses In Qatar
}

\section{Saiful Uddin 1}

1 Messaieed Medical Center Qatar Petroleum

\section{Article Info}

\section{Article History:}

Accepted May 7th, 2019

\section{Key words:}

Job satisfaction; Nurse;

Working time arrangements

\section{INTRODUCTION}

Qatar is a rich country with high economic growth due to oil and natural gas. The rapid development and development that is taking place in Qatar will automatically provide extensive employment opportunities including the health sector. There are opportunities That is one reason that Indonesian nurses migrated to Qatar in hopes of getting a better life.

\begin{abstract}
Indonesian nurses migrated out of the country with various motifs, for instance, to earn a better income, enhancing the experience, personal development, and improvement of nursing ability. The phenomenon where nurses turn over from their job can also be caused by job dissatisfaction. Nurses job's satisfaction needs serious attention since the nurses are spearheading the implementation of services. The objective of this study to get an idea of the level of job satisfaction and to identify factors affecting job satisfaction in Indonesian migrants nurse in Qatar. The research method is a descriptive analytic using cross-sectional approach. The research's sample represents a total sample of 39 Indonesian nurses who work in an outpatient clinic in Qatar in February 2012. The results showed that Indonesian migrant nurses working in Qatar are satisfied with the work of $51.3 \%$. The results of the analysis showed no correlation between length of service and working time arrangements with job satisfaction, whereas there was no correlation between age, education degree and family status with job satisfaction. The recommendations can be given to health care management in Qatar are to further improve the promotion system and nurses self-development and to increase incentives for nurses who do shift duty. Nurses are advised to increase the level of education and improve the performance of work.
\end{abstract}

With the increasing number of Indonesian migrant nurses in Qatar, there is a phenomenon and dynamics of the lives of nurses abroad. Mingling with the international community with a variety of cultural backgrounds, customs, beliefs, and different languages gives rise to their own stories and impressions. Discrimination with native Qatari including work and salary amounts contribute to making Indonesian nurses satisfied or not at work, which also relates to feeling comfortable and at home abroad.

Corresponding author:

Saiful Uddin

saifindo@yahoo.com

South East Asia Nursing Research, Vol 1 No 1, June 2019

ISSN:2685-032X

DOI: https://doi.org/10.26714/seanr.1.1.2019.1-6 
Job satisfaction is an expression of one's feelings and expressions when he can or cannot fulfill the expectations of the work process and its performance. Job satisfaction is not a single dimension concept, but rather a multifaceted concept which means that job satisfaction is influenced by a number of factors. In addition to salary problems, many other factors influence nurse job satisfaction. The factors that can affect an employee's job satisfaction are the contents of work, appearance, actual work assignments and as control of work, supervision, organization and management, opportunities for advancement, salaries and other financial benefits such as incentives, work colleagues, and work conditions. ${ }^{1}$ Whereas according to demographic characteristics also affect job satisfaction. $^{2}$

Other research declares that there is no relationship between nurse job satisfaction and age, and there is no relationship between job satisfaction and the length of employment of nurses. ${ }^{3}$ Meanwhile, Setiawan's (2007) study states that there is a relationship between age, and marital status with nurse job satisfaction and the absence of a relationship between sex, work period and level of education with nurse job satisfaction. ${ }^{4}$

An interview with several nurses working in Qatar showed data that most felt comfortable working in Qatar. Other data shows that for 4 years from 2007 to 2011, out of 53 nurses working in one health care institution, only 1 nurse (1.8\%) resigned and returned to Indonesia, with a $0 \%$ turnover rate. In fact, the number is increasing with the arrival of new nurses and those who are still in the process of recruitment. This phenomenon is very different from the experience of working for 6 years in the UAE (United Arab Emirates), in the first 2 years almost half of the women who resigned. Hardy (2010) also stated that the resignation of Indonesian nurses significantly occurred in
Kuwait, Saudi and UAE. In accordance with the other study that resignation can be related to job satisfaction. ${ }^{1,5}$

Nurse job satisfaction needs to get serious attention from the management and nurses themselves because nurses are the spearhead of implementing services and personnel who interact directly with patients and families of patients. The image of a health institution is influenced by the services provided by nurses. Besides for the institution, job satisfaction is also beneficial for the nurse's own health. The level of job satisfaction and health can be mutually reinforcing so that an increase from one can increase the other and vice versa a decline has a negative effect on the other. ${ }^{6}$

Job satisfaction problems can have a big impact on productivity, performance, service, absenteeism, turnover and so on. Achievement of nurse job satisfaction can provide many benefits for the nurse herself and the institution where she works, and of course the client or community at large recipient of nursing services.

For Indonesian migrant nurses in Qatar, job satisfaction gives a deeper meaning. Far from home and far from relatives, job satisfaction is expected to provide more benefits, such as increasing support for nurses to survive overseas. Conversely, a low level of job satisfaction will affect behavior and personal life that is less comfortable, which in turn can encourage high levels of resignation and turnover. Based on the above things, it is interesting to study and examine what factors are related to the job satisfaction of Indonesian migrant nurses in Qatar.

\section{METHODS}

The type of research used is descriptive analytic research to make a picture of the analysis of the relationship between two variables in a situation or group of subjects. The research design used is a Cross- 
Sectional approach considering the assessment of a nurse's perception of feelings towards his work can only be done for a moment because a person's perception is likely to change at any time.

The sample in this study was taken by purposive sampling technique. The total sample of all Indonesian migrant nurses in Qatar amounted to 39 people who were in accordance with the criteria of inclusion and research exclusion. This research was conducted in Qatar in the span of time from 15 February 2012 to 29 February 2012. Tools for collecting data using questionnaires that have been tested for validity and reliability. The questionnaire consists of 2 sets, namely questionnaires to assess the characteristics of respondents and questionnaires to determine the level of job satisfaction of respondents.

Data were analyzed univariately to see the frequency and distribution of respondents based on demographic characteristics and job characteristics and to know the level of job satisfaction of respondents. Then bivariate analysis to see the relationship between the independent variable and the dependent variable using the Chi-Square correlation and Rank Spearman test.

\section{RESULTS}

The results of the study on 39 respondents showed that the age of the respondents was at an average age of 37.7 years with the age of the youngest 31 years and the oldest 46 years. Judging from other demographic characteristics, it can be seen that Indonesian nurses in Qatar are mostly male sex $87.2 \%$. The working period is between 1 and 10 years. The majority of nurses live with families in Qatar and work in shifts. The education level of the majority of Indonesian migrant nurses in Qatar is diploma graduates which are equal to $56.4 \%$, then Senior High School (SPK) as many as 12 people (30.8\%) and those who hold nursing degrees both S1 and S2 are 5 (12\%).
In general Indonesian nurses working in Qatar were satisfied with their work (51.3\%). There is no relationship between age and job satisfaction of Indonesian migrant nurses in Qatar. There is a relationship between the tenure and the job satisfaction of Indonesian migrant nurses in Qatar. There is no relationship between the level of education and the job satisfaction of Indonesian migrant nurses in Qatar. There is no relationship between marital status and job satisfaction of Indonesian migrant nurses in Qatar. Job satisfaction factors for Indonesian migrant nurses in Qatar, which are statistically proven to be related to overall job satisfaction are work periods and work time arrangements.

Table 1

Distribution of Indonesian migrant nurses in Qatar based on the level of job satisfaction

\begin{tabular}{lcc}
\hline \multicolumn{1}{c}{ Level of job satisfaction } & f & $\%$ \\
\hline Satisfied & 20 & 51,3 \\
Not satisfied & 19 & 48,7 \\
\multicolumn{1}{c}{ amount } & 39 & 100 \\
\hline
\end{tabular}

Table 2

Distribution of Indonesian migrant nurses in Qatar based on age, employment rates and job satisfaction

\begin{tabular}{clcc}
\hline $\begin{array}{c}\text { Bivariate } \\
\text { correlation }\end{array}$ & \multicolumn{1}{c}{ Variable } & $\begin{array}{c}\text { Coefficient } \\
\text { Correlation }\end{array}$ & P-Value \\
\hline Spearman's rho & $\begin{array}{l}\text { age vs job } \\
\text { satisfaction }\end{array}$ & $.359^{*}$ & 0.025 \\
\cline { 2 - 4 } & $\begin{array}{l}\text { Working } \\
\text { period vs. }\end{array}$ & $.359^{*}$ & 0.025 \\
& $\begin{array}{l} \\
\text { job } \\
\text { satisfaction }\end{array}$ & \\
\hline
\end{tabular}

Table 3

Distribution of Indonesian migrant nurses in Qatar based on education, family status level, and job satisfaction

\begin{tabular}{lccccc}
\hline & \multicolumn{5}{c}{ Job satisfaction } \\
Level of education & \multicolumn{2}{c}{ Satisfied } & \multicolumn{2}{c}{ Not } & \\
& $\mathrm{f}$ & $\%$ & $\mathrm{f}$ & $\%$ & $\mathrm{p}$ \\
& 7 & 58,3 & 5 & 41,7 & \\
\hline Senior High School & 10 & 45,5 & 12 & 54,5 & 0,738 \\
$\begin{array}{l}\text { Diploma } \\
\text { Bachelor and }\end{array}$ & 3 & 60 & 2 & 40 & \\
Master & 14 & 48,3 & 15 & 51,7 & \\
\hline $\begin{array}{l}\text { Marry (live with } \\
\text { family) }\end{array}$ & & & & & 0,522 \\
Single (live alone) & 6 & 60 & 4 & 40 & \\
\hline
\end{tabular}


Table 4

Distribution of Indonesian migrant nurses in Qatar based on work time arrangements and job satisfaction

\begin{tabular}{|c|c|c|c|c|c|c|}
\hline \multirow{3}{*}{$\begin{array}{c}\text { Working } \\
\text { time } \\
\text { settings }\end{array}$} & \multicolumn{4}{|c|}{ Job satisfaction } & \multirow{3}{*}{$\begin{array}{c}\text { OR } \\
(95 \% \\
C I)\end{array}$} & \multirow{3}{*}{$\mathrm{p}$} \\
\hline & \multicolumn{2}{|c|}{ satisfied } & \multicolumn{2}{|c|}{$\begin{array}{c}\text { Not } \\
\text { satisfied }\end{array}$} & & \\
\hline & f & $\%$ & f & $\%$ & & \\
\hline & 11 & 39,3 & 17 & 60,7 & 0,144 & 0,017 \\
\hline Not S & 9 & 81,8 & 2 & 18,2 & & \\
\hline
\end{tabular}

\section{DISCUSSION}

Based on the characteristics of the demographics of Indonesian nurses in Qatar, most of them are male, mature, live with family and are educated by the nursing academy. Whereas based on the characteristics of its work, most of the work period in Qatar is relatively long, namely 5 years and above and working shifts.

The age of Indonesian migrant nurses in Qatar is in the range of 31 to 46 years, showing a relatively long maturity and possible work experience. The age group that is mostly over 36 years is 25 people. Satisfaction in the aspect of work for Indonesian migrant nurses in Qatar seen from the age factor can be used as evidence because age over 35 years can lead to feelings of satisfaction with work. ${ }^{6,7}$

The results of this study also show that the working period of Indonesian migrant nurses working in Qatar is relatively long, namely 5 years and over as many as 27 people. Because the majority of the working period is longer than the new, the level of job satisfaction of Indonesian migrant nurses working in Qatar is high, this is consistent with the long working period will stimulate increased job satisfaction. ${ }^{8}$

The education level of Indonesian migrant nurses who work in Qatar is mostly nursing graduates with $56.4 \%$. Although in this study the education level of Indonesian migrant nurses working in Qatar was not statistically related to job satisfaction, nurses were required to improve their abilities and education to face the era of globalization.

Most Indonesian migrant nurses working in Qatar live in Qatar together with their families $(74.4 \%)$. because indeed most nurses get family status facilities from companies or hospitals where they take shelter so they can invite families to stay in Qatar. The tendency to feel satisfied with the work of nurses who live with family is higher than the nurse who lives single. This is based on the fact that nurses who live with spouses and children of wives will feel more calm and comfortable.

Indonesian migrant nurses who work in Qatar, mostly shift work. Nurses involved in the rotation shift system will change their working time which is usually morning, evening and evening, according to the specified rotation shift system. Besides having a positive aspect of maximizing existing resources, work shifts will have risks and affect workers socially, physically and psychologically such as dissatisfaction and irritation.

In general, job satisfaction assessments by Nurses of Indonesian migrant nurses in Qatar are balanced between those who value being satisfied with those who are dissatisfied. The number of satisfied nurses as many as 21 people against the dissatisfied there are 18 people. Job satisfaction is a condition felt by someone who is the result of comparing the appearance or outcome (product) that is felt in relation to one's expectations. ${ }^{9}$

Judging from the results of the research answers the questions with the highest percentage of satisfaction is in the questions about work facilities and infrastructure, environmental hygiene, information and support/assistance of superiors to nurses in completing nursing tasks. While the aspects that cause the highest dissatisfaction are opportunities 
for promotion and self-development, as much as $30.8 \%$.

Based on the results of the study it was found that there was no relationship between age and job satisfaction of Indonesian migrant nurses working in Qatar. Analysis of researchers, this result is supported by the fact that the age of most Indonesian migrant nurses in Qatar is included in the adult group and has worked in other places so that they have a comparison of the main factors of work.

The results of this study contradict the theory which states that age has an effect on job satisfaction and the older the employee, the higher the level of satisfaction. ${ }^{5,6}$ This is supported by a number of reasons including the further age of a person, the more difficult it is to start a new career in a new place, an established lifestyle, and an inner bond and friendship between those who are friends in the organization, on the contrary easy to guess for employees who are more young, the desire to move is greater. ${ }^{9}$

The results of Rank Spearman analysis showed that $p=0.025(p<0.05)$ or there was a relationship between years of service and job satisfaction of Indonesian migrant nurses in Qatar. Nurses whose work period is more than 5 years give a satisfied rating of 18 people (66.7\%), while nurses who have a working period of 4 years and under there are 3 people or $(25.0 \%)$ who claim to be satisfied with their work. This is in line with the statement that stated that the working period was consistently associated negatively with the entry and exit of employees and was stated as one of the best single forecasters for job satisfaction when viewed from the entry and exit of employees or nurses. ${ }^{8}$

The test results using Chi-Square showed that $\mathrm{p}=0.738(\mathrm{p}>0.05)$ or there was no relationship between the level of education and the job satisfaction of Indonesian migrant nurse nurses in Qatar. This is not in accordance with the statement of another study who concluded that employees with advanced education felt very satisfied with the work they did. ${ }^{7}$ The absence of a statistical relationship between the level of education and the job satisfaction of Indonesian nurses in Qatar can be caused because there is no difference in the types of employment contracts, staffing, salaries/incentives and benefits between employees who have low or high levels of education

Family status or residence whether or not someone is with the family will affect a person's behavior in organizational life, including expectations and demands on work/company organization. The test results using Chi-Square show that there is no relationship between family status and Indonesian migrant nurse's job satisfaction in Qatar because the p-value obtained is $0.522(p>0.05)$. progress in the field of communication that makes it easy for people to connect long distances both through sound and image/video may be one of the factors that cause the absence of a relationship between nurses who live with family and those who live alone in Qatar. Another factor is for single nurses (alone) can take twice a year leave plus tickets.

The results showed that there was a relationship between setting work time and job satisfaction for Indonesian migrant nurses in Qatar. From the result, There is a significant (very large) difference between non-shift nurses and shift workers in answering job satisfaction in Qatar. Most non-shift nurses or $81.8 \%$ said they were satisfied with their work, while shift work nurses were only $42.9 \%$ who expressed satisfaction with their work.

The existence of a statistical relationship between the regulation of work time and job satisfaction, in line with the statement that shift work is related to social, physical and psychological problems including job satisfaction and stress.1,6,7 Even so, the 
rotation shift work system has a positive aspect, namely empowering existing resources optimally. Looking at the effects of shift work which affects many aspects including job satisfaction, it is appropriate for management to provide special incentives for nurses who carry out shift work.

\section{CONCLUSION}

The results of the study were conducted on Indonesian migrant nurses in Qatar with 39 respondents working in outpatient clinics. Variables studied included job satisfaction, age, years of service, education level, family status and division of work time. The results of the test of job satisfaction analysis for Indonesian migrant nurses in Qatar showed 51.3\%. While the correlation between age, education level and family status with job satisfaction are not related. Conversely, there is a meaningful relationship between years of work and work time arrangements with job satisfaction.

This research is useful as information and evaluation of implementation and obstacles in achieving nurse job satisfaction abroad, especially in Qatar, so the authors expect nurses in Qatar and those who will go abroad to prepare themselves both physically and mentally, with additional training and increase their education level. Recognizing local customs and culture as well as work-related factors will also help nurses to better adapt to the workplace and work well so that they can achieve job satisfaction as expected.

\section{CONFLICTS OF INTEREST}

The author declares that none of him had any conflict of interests.

\section{REFERENCES}

1. Rivai V. Manajemen sumber daya manusia untuk perusahaan: dari teori ke praktik [Internet]. Banjarmasin: Rajawali Pers; 2009 [cited 2010 Jun 21]. 1087 p. Available from:
https://books.google.co.id/books?id=Rb7qZw EACAAJ\&dq=Manajemen+sumber + daya + manu sia+untuk+perusahaan+dari+teori+ke+praktik \&hl=id\&sa=X\&ved=0ahUKEwjc4paY0_niAhXEx FkKHbPYBMQQ6AEIKDAA

2. CUMMINGS GG, OLSON K, HAYDUK L, BAKKER D, FITCH M, GREEN E, et al. The relationship between nursing leadership and nurses' job satisfaction in Canadian oncology work environments. J Nurs Manag [Internet]. 2008 Jul 1 [cited 2019 Jun 21];16(5):508-18. Available from: http://doi.wiley.com/10.1111/j.13652834.2008.00897.x

3. Gustian Y. Hubungan Stres Kerja Dengan Kinerja Perawat Pelaksana Dalam Melaksanakan Asuhan Keperawatandi Ruang Rawat Inap RSUD Pasaman Barat Tahun 2010. 2010 Oct 21 [cited 2017 Jun 21]; Available from: http://repo.unand.ac.id/398/

4. Teguh Setiawan 6450402559. Hubungan Antara Karakteristik IndividuDengan Kepuasan Kerja Perawat Pelaksana Di RSBanyumanik. 2007 Mar 30 [cited 2019 Jun 21]; Available from: https://lib.unnes.ac.id/1118/

5. Riani AL. Manajemen Sumber Daya Manusia Masa Kini. Edisi Pert. Yogyakarta: Graha Ilmu; 2013.

6. Munandar AS. Psikologi Industri dan Organisasi. Jakarta: UI-Press; 2008.

7. Waluyo M. Psikologi Teknik Industri. In: Edisi 1. Yogyakarta: Graha Ilmu; 2009.

8. Robbins SP, Judge T. Organizational behavior. Edition 16. Boston: Pearson; 2015. xxxiii, 709 pages.

9. Siagian SP. Kiat Meningkatkan Produktivitas Kerja. Jakarta: Rineka Cipta; 2009. 